\title{
Urease and nitrification inhibitors with pig slurry effects on ammonia and nitrous oxide emissions, nitrate leaching, and nitrogen use efficiency in perennial ryegrass sward
}

\author{
Sang Hyun Park1, Bok Rye Lee ${ }^{2}$, and Tae Hwan Kim"*
}

\author{
* Corresponding Author: Tae Hwan Kim \\ Tel: +82-62-530-2126, Fax: +82-62-530-2129, \\ E-mail: grassl@chonnam.ac.kr \\ ${ }^{1}$ Department of Animal Science, College \\ of Agriculture \& Life Science, Chonnam \\ National University, Gwangju 61186, Korea \\ 2 Biotechnology Research Institute, Chonnam \\ National University, Gwangju 61186, Korea \\ ORCID \\ Sang Hyun Park \\ https://orcid.org/0000-0002-8766-5077 \\ Bok Rye Lee \\ https://orcid.org/0000-0002-1912-0390 \\ Tae Hwan Kim \\ https://orcid.org/0000-0002-9202-1655
}

Submitted Jan 27, 2021; Revised Mar 12, 2021; Accepted Apr 6, 2021
Objective: The present study was conducted to assess the effect of urease inhibitor (hydroquinone $[\mathrm{HQ}]$ ) and nitrification inhibitor (dicyandiamide $[\mathrm{DCD}]$ ) on nitrogen $(\mathrm{N})$ use efficiency of pig slurry for perennial ryegrass regrowth yield and its environmental impacts. Methods: A micro-plot experiment was conducted using pig slurry-urea ${ }^{15} \mathrm{~N}$ treated with $\mathrm{HQ}$ and/or DCD and applied at a rate of $200 \mathrm{~kg} \mathrm{~N} / \mathrm{ha}$. The flows of $\mathrm{N}$ derived from the pig slurry urea to herbage regrowth and soils as well as soil $\mathrm{N}$ mineralization were estimated by tracing pig slurry-urea ${ }^{15} \mathrm{~N}$, and the $\mathrm{N}$ losses via ammonia $\left(\mathrm{NH}_{3}\right)$, nitrous oxide $\left(\mathrm{N}_{2} \mathrm{O}\right)$ emission, and nitrate $\left(\mathrm{NO}_{3}^{-}\right)$leaching were quantified for a $56 \mathrm{~d}$ regrowth of perennial ryegrass (Lolium perenne) sward.

Results: Herbage dry matter at the final regrowth at $56 \mathrm{~d}$ was significantly higher in the HQ and/or DCD applied plots, with a $24.5 \%$ to $42.2 \%$ increase in ${ }^{95} \mathrm{~N}$ recovery by herbage compared with the control. Significant increases in soil ${ }^{15} \mathrm{~N}$ recovery were also observed in the plots applied with the inhibitors, accompanied by the increased $\mathrm{N}$ content converted to soil inorganic $\mathrm{N}\left(\mathrm{NH}_{4}{ }^{+}+\mathrm{NO}_{3}{ }^{-}\right)(17.3 \%$ to $28.8 \%$ higher than that of the control). The estimated loss, which was not accounted for in the herbage-soil system, was lower in the plots applied with the inhibitors (25.6\% on average) than that of control (38.0\%). Positive effects of urease and/or nitrification inhibitors on reducing $\mathrm{N}$ losses to the environment were observed at the final regrowth $(56 \mathrm{~d})$, at which cumulative $\mathrm{NH}_{3}$ emission was reduced by $26.8 \%$ (on average 3 inhibitor treatments), $\mathrm{N}_{2} \mathrm{O}$ emission by $50.2 \%$ and $\mathrm{NO}_{3}{ }^{-}$leaching by $10.6 \%$ compared to those of the control.

Conclusion: The proper application of urease and nitrification inhibitors would be an efficient strategy to improve the $\mathrm{N}$ use efficiency of pig slurry while mitigating hazardous environmental impacts.

Keywords: Lolium perenne; Nitrification Inhibitor; Pig Slurry; Regrowth; Urease Inhibitor

\section{INTRODUCTION}

Nitrogen $(\mathrm{N})$ is an essential nutrient as a key limiting factor of the growth and development of plants in agricultural ecosystems [1]. Incremental increases in global crop yields during the past several decades has mainly been dependent on the increasing application of synthetic $\mathrm{N}$ fertilizers. Animal manures have long been used as alternative organic $\mathrm{N}$ fertilizers. Most of the $\mathrm{N}$ in feces is present in organic form, while in urine, $65 \%$ to $90 \%$ of the $\mathrm{N}$ is present as urea [2]. In Korea, pig slurry is the most viable recycling option and represents more than $80 \%$ of all recycled animal manure [3] because pig farms usually have little or no arable land for forage production.

The amount of $\mathrm{N}$ supplied to agro-ecosystems is often higher than $\mathrm{N}$ uptake by crops. An excessive $\mathrm{N}$ input leads to $\mathrm{N}$ losses via volatilization of ammonia $\left(\mathrm{NH}_{3}\right)$, emission of 
nitrous oxide $\left(\mathrm{N}_{2} \mathrm{O}\right)$, and leaching of $\mathrm{NO}_{3}{ }^{-} \mathrm{N}$, which pose a significant threat to the environmental quality of the atmosphere and aquatic systems [4]. Thus, management of $\mathrm{N}$ nutrition is important to increase crop productivity and control environmental pollution. The chemical or organic $\mathrm{N}$ applied to the soil, mainly in form of urea, hydrolyze into $\mathrm{NH}_{4}{ }^{+}$, hydroxyl, and carbonate ions by the microbial urease mediation. The $\mathrm{NH}_{4}^{+}$produced then converts to $\mathrm{NH}_{3}$, which can be lost through volatilization under alkaline conditions. If soil condition does not favor volatilization, $\mathrm{NH}_{4}^{+}$can either be held in the soil via cation exchange or converted to $\mathrm{NO}_{3}^{-}$, leading to $\mathrm{N}$ losses through leaching or denitrification. A proportion of volatilized and deposited $\mathrm{NH}_{3}$ can generate $\mathrm{N}_{2} \mathrm{O}$, which is a long-lasting greenhouse gas, through both nitrification, in which aerobic oxidation of $\mathrm{NH}_{4}^{+}$to $\mathrm{NO}_{2}^{-}$and further $\mathrm{NO}_{3}{ }^{-}$, and denitrification, in which $\mathrm{NO}_{3}{ }^{-}$is reduced to $\mathrm{N}_{2} \mathrm{O}$ [5].

Various management practices and technologies have attempted to enhance $\mathrm{N}$ fertilizer use efficiency while minimizing $\mathrm{N}$ losses to the environment. One of the strategies is the use of inhibitors of urea hydrolysis (urease inhibitors) and of ammonia oxidation (nitrification inhibitors), which have been shown to be effective in enhancing $\mathrm{N}$ use efficiency by delaying nitrification/denitrification [6,7]. The efficacy of urease and/or nitrification inhibitors in mitigating $\mathrm{NH}_{3}$ and $\mathrm{N}_{2} \mathrm{O}$ emissions varies with soil $\mathrm{pH}$ [8], type and level of applied $\mathrm{N}$ sources [9], the concentration of inhibitors [10], soil texture [11], as well as climatic factors such as rainfall [12]. Martins et al [7] showed that the urease and nitrification inhibitors enhanced urea $-{ }^{15} \mathrm{~N}$ recovery by maize and increased grain yield. In a meta-analysis with 111 datasets from 39 studies [5], nitrification inhibitors are effective in reducing $\mathrm{N}_{2} \mathrm{O}$ emissions with the highest inhibitory effect in grassland and followed by cropland, upland, and paddy. Li et al [13] reported that $\mathrm{N}_{2} \mathrm{O}$ emission was efficiently lower in urea together with urease and nitrification inhibitors than with either a single urease or nitrification inhibitor. However, the flux of $\mathrm{N}$ derived from animal manure to pasture plants and soil has not been fully elucidated. In addition, few studies have assessed the effects of inhibitors on gaseous emissions and nitrate leaching from animal manure-based $\mathrm{N}$ [14].

In the present study, we hypothesized that the synergistic effect of urease inhibitor (hydroquinone [HQ]) and nitrification inhibitor (dicyandiamide [DCD]) may improve $\mathrm{N}$ use efficiency of pig slurry and minimize the $\mathrm{N}$ losses to the environment by regulating $\mathrm{N}$ mineralization processes in soil. To test this hypothesis, the turnover of pig slurry-urea ${ }^{15} \mathrm{~N}$ and its flow into the plant and soil inorganic $\mathrm{N}$ components were directly quantified while accounting for $\mathrm{N}$ losses to the environment $\left(\mathrm{NH}_{3}\right.$ and $\mathrm{N}_{2} \mathrm{O}$ emissions and nitrate leaching). The resulting data were interpreted regarding the effectiveness of HQ and/or DCD.

\section{MATERIALS AND METHODS}

\section{Experimental design}

The study was based on field experiments conducted on a permanent grass sward consisting mainly of perennial ryegrass (Lolium perenne) on sandy loamy soil. The soil chemical properties of the experimental site are presented in Table 1. During the experimental period, the typical climate was temperate with high humidity, with an average temperature of $22.5^{\circ} \mathrm{C}$ and total precipitation of $420 \mathrm{~mm}$. Four treatments of slurry application were compared: i) only pig slurry as a control, ii) HQ treatment (pig slurry + urease inhibitor [HQ, $\left.\mathrm{C}_{6} \mathrm{H}_{6} \mathrm{O}_{2}\right]$ ), iii) DCD treatment (pig slurry + nitrification inhibitor [DCD, $\left.\mathrm{NH}_{4} \mathrm{~F}\right]$ ), and iv) HQ and DCD combination treatment. The experiment in a randomized complete block design consisted of four replications. Each treatment plot measured $2.5 \mathrm{~m} \times 10$ length experiment and contained 12 micro-plots $(0.5 \mathrm{~m} \times 0.5 \mathrm{~m})$ for monitoring the fate of ${ }^{15} \mathrm{~N}$-labeled pig slurry. To prevent surface runoff and contamination by slurry application, there was a $2 \mathrm{~m}$ margin between plots with a $0.45 \mathrm{~m}$ metal retainer inserted $30 \mathrm{~cm}$ deep soil. The bottomless acrylic chambers $(0.2 \mathrm{~m}$ diameter and $0.3 \mathrm{~m}$ length) were used for collecting gas samples and suction cups (P80, eco Tech, Bonn, Germany) for collecting leachate samples.

\section{Pig slurry treatments and ${ }^{15} \mathrm{~N}$ labeling}

The pig slurry was obtained from pig livestock farm and stored in concrete tanks at ambient temperature for approximately 1 week. Four different $400 \mathrm{~L}$ plastic containers filled with pig slurry were mixed with $0.3 \%$ HQ or $5 \%$ DCD of the total-N in pig slurry, respectively. The slurry urea fraction of four treatments were labeled by thoroughly mixing with highly enriched ${ }^{15} \mathrm{~N}$ urea $\left(98 \%{ }^{15} \mathrm{~N}\right.$ atom excess) just before application. The applied pig slurries were analyzed at the time of application. The pig slurry contained on average $\left(\mathrm{kg} / \mathrm{m}^{3}\right)$ $1.58 \pm 0.32$ total $\mathrm{N}, 0.98 \pm 0.12$ urea, $0.199 \pm 0.02 \mathrm{NH}_{4}{ }^{+}-\mathrm{N}$ and

Table 1. Soil chemical properties of experimental site

\begin{tabular}{|c|c|c|c|c|c|c|c|c|}
\hline \multirow{2}{*}{ Items } & \multirow{2}{*}{ pHwater (1:5) } & \multirow{2}{*}{$\mathrm{EC}(\mathrm{Ds} / \mathrm{m})$} & \multirow{2}{*}{ OM (\%) } & \multirow{2}{*}{ Total N (\%) } & \multirow{2}{*}{ Available P (mg/kg) } & \multicolumn{3}{|c|}{ Exchangeable cation $\left(\mathrm{cmol}^{+} / \mathrm{kg}\right)$} \\
\hline & & & & & & K & $\mathrm{Ca}$ & $\mathbf{M g}$ \\
\hline Soil & 6.2 & 0.69 & 2.21 & 0.14 & 243.3 & 0.21 & 2.67 & 1.74 \\
\hline
\end{tabular}

EC, electric conductivity; OM, organic matter. 
$0.143 \pm 0.01 \mathrm{NO}_{3}{ }^{-}-\mathrm{N}$ with ${ }^{15} \mathrm{~N}$-urea enrichment of $5.001 \pm 0.012$ atom \%. Treated pig slurry at a rate of $200 \mathrm{~kg} \mathrm{~N} / \mathrm{ha}$ (e.g., 316 L per $25 \mathrm{~m}^{2}$ plot, which contained $95.8 \mathrm{~kg} \mathrm{P} / \mathrm{ha}$ and $127 \mathrm{~kg}$ $\mathrm{K} / \mathrm{ha}$ ) was applied after herbage was cut at $50 \mathrm{~mm}$ above ground level [3].

\section{Herbage, soil, gases, and leachate sampling}

The herbage sample was harvested from four randomly placed micro-plots by cutting manually, and the remained stubble was approximately $50 \mathrm{~mm}$. About $500 \mathrm{~g}$ of collected herbage sample was chopped into $20 \mathrm{~mm}$ long segments, and then lyophilized, ground, and stored in a vacuum desiccator for chemical analysis. The soil samples were collected by soil cores ( 0 to $0.3 \mathrm{~m}$ depth) randomly using a $0.3 \mathrm{~m}$ diameter tube auger in the same micro-plots that herbage sampling place. The collected soil samples were air-dried, ground, and sieved to $<0.15 \mathrm{~mm}$. The herbage and soil sampling were done at 7, 14, and $56 \mathrm{~d}$ after pig slurry application, respectively.

Airtight acrylic chambers were located to $50 \mathrm{~mm}$ depth soil in each experimental plot for gas sampling. To collect $\mathrm{NH}_{3}$ emission, the acid trap system method was used as described by Ndegwa et al [15] with modifications. Each chamber was connected to $\mathrm{NH}_{3}-\mathrm{N}$ trapping bottles containing $150 \mathrm{~mL}$ of $0.2 \mathrm{~mol} / \mathrm{L} \mathrm{H}_{2} \mathrm{SO}_{4}$ and a vacuum system to pull air through the chambers. The $\mathrm{NH}_{3}-\mathrm{N}$ traps a constant rate of $1.5 \mathrm{~L}$ per minute. Each chamber was closed with silicon sealing and clamped for 24 hours. The $\mathrm{NH}_{3}$ sampling in each treatment block was done at the same time over 1 hour to avoid the impact of extraneous gases. The $\mathrm{N}_{2} \mathrm{O}$ gas was collected by using a syringe before $\mathrm{NH}_{3}$ emission sampling and then stored in $10 \mathrm{~mL}$ of vacutainer tuber. The gas of $\mathrm{NH}_{3}$ and $\mathrm{N}_{2} \mathrm{O}$ was collected daily for the first $14 \mathrm{~d}$, then at intervals 1 to 2 weeks. The leachate samples were obtained by suction cups in each plot at a depth of $0.5 \mathrm{~m}$ for $\mathrm{NO}_{3}^{-}-\mathrm{N}$ analysis. Soil water samples were obtained by applying a tension -250 hPa. A sampling of $\mathrm{NO}_{3}^{-}-\mathrm{N}$ was done weekly and stored at $-20^{\circ} \mathrm{C}$.

\section{Measurements and chemical analysis}

The herbage was harvested from each micro-plot and converted to $\mathrm{kg} / \mathrm{ha}$. To calculate the $\mathrm{N}$ recovery in herbage $(\mathrm{kg}$ $\mathrm{N} / \mathrm{ha}$ ), the converted estimate was multiplied by the $\mathrm{N}$ concentration determined in the subsamples. The stable isotope ratio mass spectrometer (IRMS, IsoPrime, GV Instrument, Manchester, UK) was used for measuring the total $\mathrm{N}$ content and ${ }^{15} \mathrm{~N}$ atom $\%$ of herbage, soil, and pig slurry samples. Inorganic nitrogen was extracted with $2 \mathrm{M} \mathrm{KCl}$ and the $\mathrm{NH}_{4}^{+}-\mathrm{N}$ was determined by distillation in an alkaline medium $(\mathrm{MgO})$. The same procedure was used for $\mathrm{NO}_{3}^{-}-\mathrm{N}$ after reduction with Devarda's alloy. The $\mathrm{N}$ liberated from each distillation was collected in $\mathrm{H}_{2} \mathrm{SO}_{4}$ and then evaporated to dryness to analyze the determination of ${ }^{15} \mathrm{~N}$ atom $\%$ excess of each $\mathrm{N}$ fraction. The total $\mathrm{N}$ and inorganic $\mathrm{N}\left(\mathrm{NH}_{4}{ }^{+} \mathrm{N}\right.$ and $\mathrm{NO}_{3}{ }^{-} \mathrm{N}$ ) concentration in soil samples were converted to $\mathrm{kg} \mathrm{N} /$ ha using soil bulk density. To determination of $\mathrm{NH}_{3}$ volatilization, the solution collected by acid traps in the form of $\left(\mathrm{NH}_{4}\right)_{2} \mathrm{SO}_{4}$ was quantified by a colorimetric determination with ammonium color reagent (Nessler's reagent, Sigma, 72190; St. Louis, MO, USA) as described by Kim and Kim [16]. $\mathrm{N}_{2} \mathrm{O}$ concentration in gas samples collected was determined using a gas chromatograph (GC-7890A, Agilent Technologies, Santa Clara, CA, USA) equipped with a thermal conductivity detector (TCD) and with a HP-Plot 5A column (30 $\mathrm{m} \times 0.53 \mathrm{~mm} \times 25 \mu \mathrm{m})$ under the following conditions: column oven temperature $40^{\circ} \mathrm{C}$; injector temperature $100^{\circ} \mathrm{C}$; detector temperature $300^{\circ} \mathrm{C}$; carrier gas helium $(2$ $\mathrm{mL} / \mathrm{min}$ ). The $\mathrm{N}_{2} \mathrm{O}$ fluxes were calculated as described by Guo et al [6]. The concentration of $\mathrm{NO}_{3}^{-}-\mathrm{N}$ leaching was determined by ion chromatography DX 120 Dionex as described by Hamonts et al [17]. The total $\mathrm{NH}_{3}, \mathrm{~N}_{2} \mathrm{O}$ emission, and $\mathrm{NO}_{3}^{-}$ leaching over the entire experimental period were calculated by the sum of daily measurements.

The determined ${ }^{15} \mathrm{~N}$ atom $\%$ excess abundances in the total $\mathrm{N}$ and inorganic $\mathrm{N}$ fractions in herbage and soil samples were converted to relative specific activity and the amount of $\mathrm{N}$ derived from pig slurry urea (NdfSU) in herbage samples was calculated as described by Park et al [18]. The ratio between the NdfSU and the quantity of applied $\mathrm{N}$ was applied for percentage of slurry urea- $\mathrm{N}$ recovery in the total $\mathrm{N}, \mathrm{NH}_{4}^{+}$, and $\mathrm{NO}_{3}{ }^{-}$fractions in herbage and soil. Therefore, the portion not recovered in herbage and soil indicate the percentage of loss.

\section{Statistical analysis}

Analysis of variance was conducted to assess the effects of urease and/or nitrification inhibitors with pig slurry at each sampling time on herbage yield, $\mathrm{N}$ uptake, gas emissions, leaching, and the fate of slurry urea-N. Statistical analysis were conducted using the SAS 9.1.3 software.

\section{RESULTS}

Dry matter, total $\mathrm{N}$ and $\mathrm{N}$ amount derived from slurry urea in herbage

Herbage dry matter (DM) was not influenced by the application of urease and nitrification inhibitors during the first $14 \mathrm{~d}$. However, at final regrowth at $56 \mathrm{~d}$, combined application of HQ and DCD (HQ+DCD) induced the highest herbage DM yield $(+30.8 \%)$, followed by DCD $(+14.5 \%)$ and HQ $(+9.6 \%)$ single applications, compared to that in the control (only pig slurry applied) (Figure 1A). Total $\mathrm{N}$ content in herbage increased only in the HQ+DCD plot from $14 \mathrm{~d}$, in which it was $21 \%$ to $33 \%$ higher than that in the control (Figure 
A

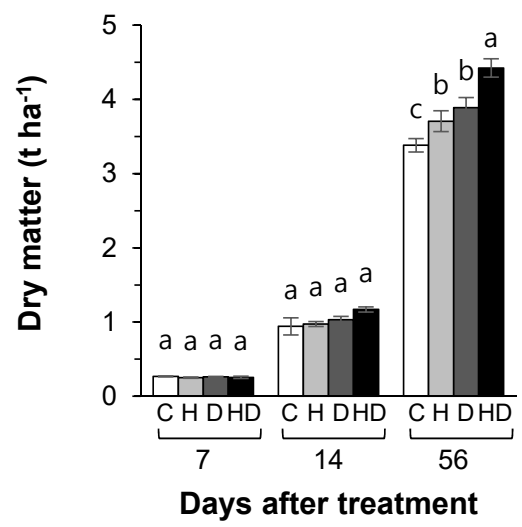

B

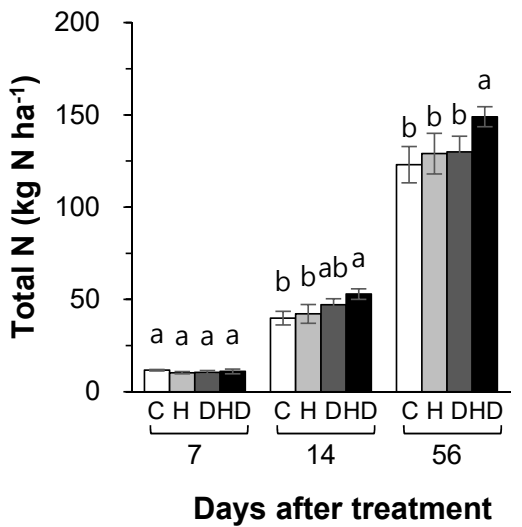

C

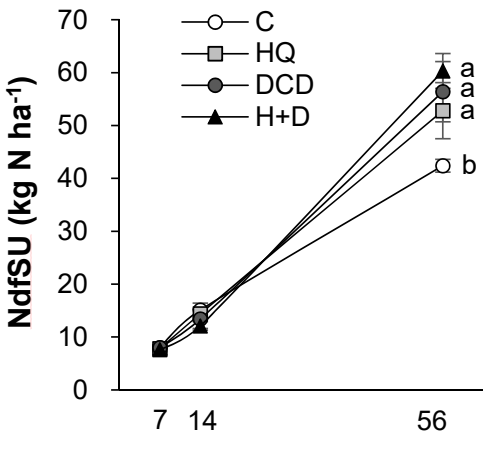

Days after treatment

Figure 1. Dry matter (A), total nitrogen (B) and the amount of $\mathrm{N}$ derived from pig slurry urea (NdfSU) (C) in herbage as affected by pig slurry with urease inhibitor $(\mathrm{HQ}, \mathrm{H})$ and/or nitrification inhibitor (DCD, D) during regrowth of perennial ryegrass sward. HQ, hydroquinone; DCD, dicyandiamide. ${ }^{a-c}$ Different letters indicate significant differences at $p<0.05$ according to the Duncan's multiple range test.

1B). The amount of NdfSU in herbage at the final regrowth at $56 \mathrm{~d}$ significantly increased only at $56 \mathrm{~d}$ by $24.5 \%, 33.0 \%$, and $42.2 \%$ in the HQ, DCD, and HQ+DCD applied plots, respectively, compared to that of the control $(\mathrm{p}<0.001)$ (Figure 1C). However, among the HQ, DCD, and HQ+DCD applied plots, there were no significant differences.

\section{Soil N dynamics}

The inhibitors (HQ and/or DCD) did not affect the total N pool size in soil throughout the regrowth period (Figure 2A). However, the NdfSU in the soil at $56 \mathrm{~d}$ increased by $11.8 \%$, $12.7 \%$, and $20.3 \%$, respectively, in the HQ, DCD, and HQ+ DCD plots compared with the control (Figure 2B). The content of $\mathrm{NH} 4+-\mathrm{N}$ in soil was significantly reduced by the

A

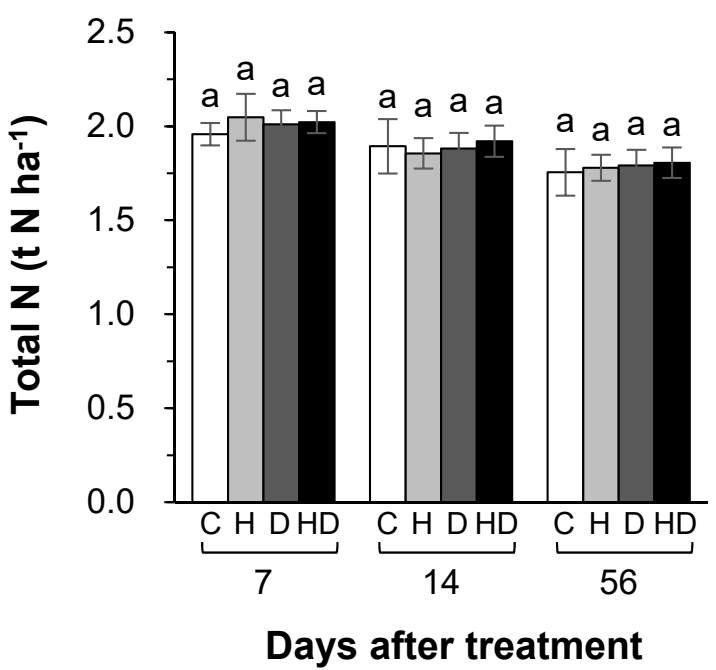

application of the inhibitors during the first $14 \mathrm{~d}$ with a stronger effect of $\mathrm{HQ}$, whereas it was higher than control in the DCD plot or recovered to the control level in the HQ and $\mathrm{HQ}+\mathrm{DCD}$ plot at $56 \mathrm{~d}$ (Figure $3 \mathrm{~A}$ ). The amount of $\mathrm{N}$ derived from slurry urea in the soil $\mathrm{NH}_{4}{ }^{+}$fraction (NdfSU$\mathrm{NH}_{4}^{+}$) during the first $14 \mathrm{~d}$ of regrowth showed a similar pattern, with a significant reduction following HQ and/or DCD application (Figure 3B). The final NdfSU- $\mathrm{NH}_{4}{ }^{+}$at $56 \mathrm{~d}$ was the highest in the HQ+DCD plot ( $4.9 \mathrm{~kg} \mathrm{~N} / \mathrm{ha}$ ) and followed by the DCD (4.2 kg N/ha), HQ $(3.0 \mathrm{~kg} \mathrm{~N} / \mathrm{ha})$, and control $(1.8 \mathrm{~kg} \mathrm{~N} / \mathrm{ha})$ plot. The content of $\mathrm{NO}_{3}^{-}-\mathrm{N}$ in the soil was lower in all plots applied with the inhibitors than that in the control throughout whole the regrowth period (Figure $3 \mathrm{C})$. The amount of $\mathrm{N}$ derived from slurry urea in the soil

\section{B}

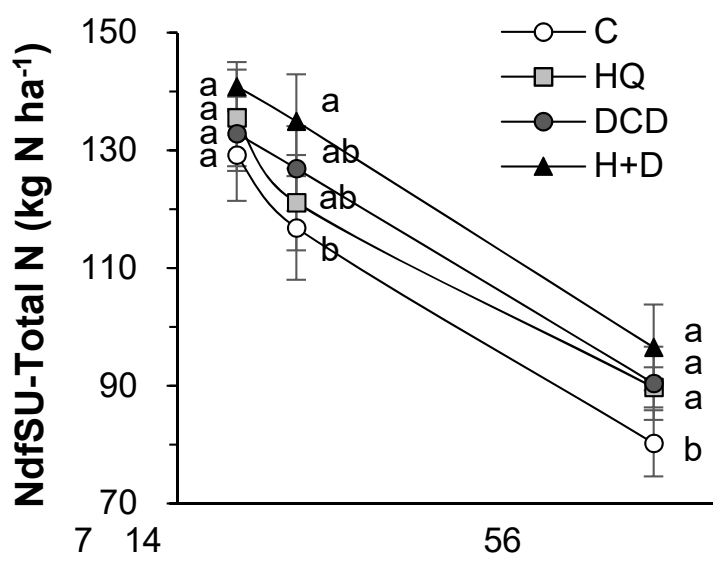

\section{Days after treatment}

Figure 2. Total $N(A)$ and the amount of $N$ derived from pig slurry urea (NdfSU) (B) in soil as affected by pig slurry with urease inhibitor (HQ, $H$ ) and/or nitrification inhibitor (DCD, D) during regrowth of perennial ryegrass sward. $H Q$, hydroquinone; $D C D$, dicyandiamide. ${ }^{a, b}$ Different letters indicate significant differences at $p<0.05$ according to the Duncan's multiple range test. 
A

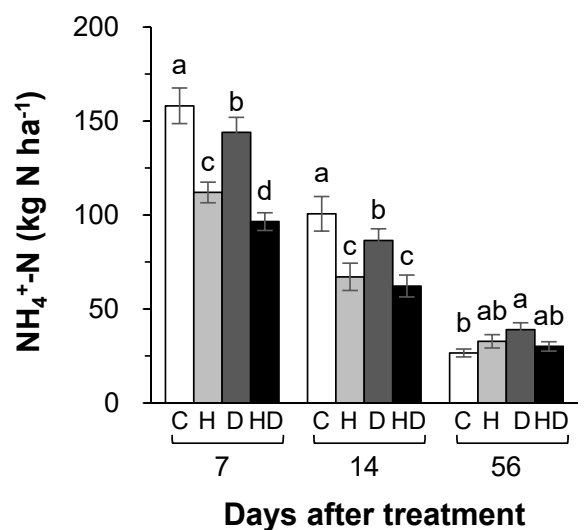

C

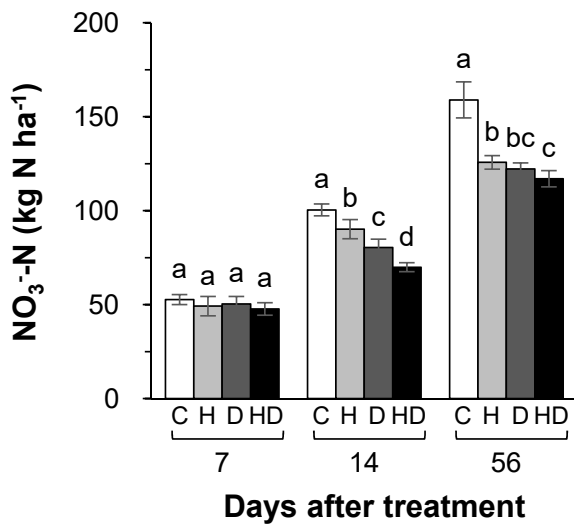

B

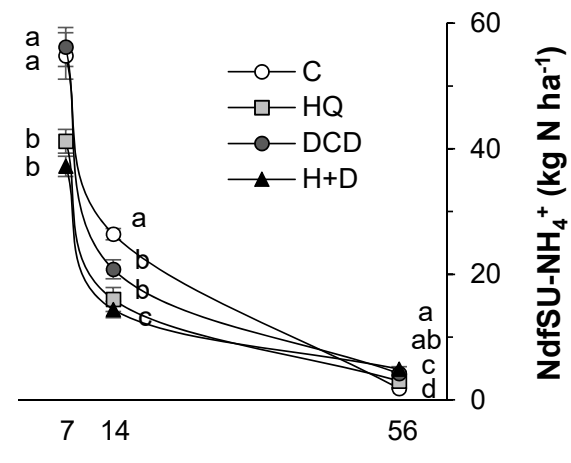

Days after treatment

D

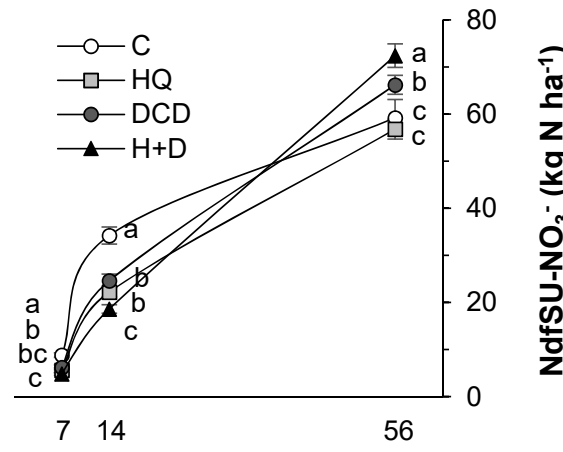

Days after treatment

Figure 3. Ammonium-N $\left(\mathrm{NH}_{4}{ }^{+} \mathrm{N}\right)(\mathrm{A})$, nitrate- $\mathrm{N}\left(\mathrm{NO}_{3}{ }^{-} \mathrm{N}\right)(\mathrm{C})$ and the amount of $\mathrm{N}$ derived from pig slurry urea (NdfSU-NH$\left.{ }_{4}{ }^{+}, \mathrm{B}\right)$ and $\mathrm{NdfSU}^{-} \mathrm{NO}_{3}{ }^{-}(\mathrm{D})$ in soil as affected by pig slurry with urease inhibitor $(\mathrm{HQ}, \mathrm{H})$ and/or nitrification inhibitor $(\mathrm{DCD}, \mathrm{D})$ during regrowth of perennial ryegrass sward. $\mathrm{HQ}$, hydroquinone; DCD, dicyandiamide. ${ }^{\text {ad }}$ Different letters indicate significant differences at $p<0.05$ according to the Duncan's multiple range test.

$\mathrm{NO}_{3}^{-}$fraction (NdfSU-NO${ }_{3}^{-}$) also remained lower until $14 \mathrm{~d}$. The final NdfSU $-\mathrm{NO}_{3}{ }^{-}$at $56 \mathrm{~d}$ significantly increased in the DCD $(+14.5 \%$ compared to that of the control) and HQ+ DCD $(+22.5 \%)$ plots (Figure 3D).

\section{Recovery of pig slurry-urea ${ }^{15} \mathrm{~N}$}

The percentage of pig slurry-urea ${ }^{15} \mathrm{~N}$ recovered in herbage averaged over all treatments gradually increased from 3.9\% (at $7 \mathrm{~d}$ ) to $26.5 \%$ (at $56 \mathrm{~d}$ ), whereas the soil ${ }^{15} \mathrm{~N}$ recovery decreased from $67.3 \%$ to $44.8 \%$ over the same period (Table 2). Thus, at the end of regrowth (56 d after pig slurry application), the herbage ${ }^{15} \mathrm{~N}$ recovered was higher in the HQ and/ or DCD plots than in the control plots, with no significant difference among the three inhibitors treatments. The soil ${ }^{15} \mathrm{~N}$ recovery was also significantly increased by the inhibitor treatments. The percentage of pig slurry-urea ${ }^{15} \mathrm{~N}$ recovered in the soil $\mathrm{NH}_{4}^{+}$and $\mathrm{NO}_{3}^{-}$fractions were also increased by application of urease and nitrification inhibitors, with the combined application of HQ and DCD showing a stronger effect. The percentage of ${ }^{15} \mathrm{~N}$ recovered in the soil inorganic $\mathrm{N}\left(\mathrm{NH}_{4}{ }^{+}\right.$and $\left.\mathrm{NO}_{3}{ }^{-}\right)$pool at $56 \mathrm{~d}$ was $22.4 \%, 33.6 \%, 31.5 \%$, and $36.2 \%$ in the control, HQ, DCD, and $\mathrm{HQ}+\mathrm{DCD}$ plots, respectively. The estimated $\mathrm{N}$ loss at the final regrowth was in the range of $21.6 \%$ to $28.4 \%$ in the plots applied with the inhibitors, and it was relatively higher in the control treatment (38.0\%).

$\mathrm{NH}_{3}, \mathrm{~N}_{2} \mathrm{O}$ emission, and $\mathrm{NO}_{3}{ }^{-}$leaching

The $\mathrm{N}$ losses through gaseous emissions of ammonia $\left(\mathrm{NH}_{3}\right)$ and $\mathrm{N}_{2} \mathrm{O}$ as well as aqueous nitrate $\left(\mathrm{NO}_{3}{ }^{-}\right)$leaching were quantified. On average, $58.8 \%$ of total $\mathrm{NH}_{3}$ emission during a $56 \mathrm{~d}$ period of regrowth occurred within the first $14 \mathrm{~d}$ after application of pig slurry to the soil. The daily $\mathrm{NH}_{3}$ emission during this period was relatively lower in the HQ and DCD $+\mathrm{HQ}$ plots than in the control and DCD plots (Figure 4A). Cumulative $\mathrm{NH}_{3}$ emission during $56 \mathrm{~d}$ of regrowth decreased by $30.0 \%, 16.3 \%$, and $34.1 \%$ in the HQ, DCD, and DCD+HQ plots compared with the control plots (Figure 5A). Consistent with $\mathrm{NH}_{3}$ emission, significant effects of inhibitors in reducing daily $\mathrm{N}_{2} \mathrm{O}$ emission was observed, with a stronger effect observed for DCD (Figure 4B). $\mathrm{N}_{2} \mathrm{O}$ emission in all treatments decreased to near the background level after $56 \mathrm{~d}$ 
Table 2. Recovery percentage of pig slurry-urea $15 \mathrm{~N}$ in herbage and soil, and calculated $\mathrm{N}$ loss as affected by pig slurry with urease inhibitor (HQ) and/or nitrification inhibitor (DCD) during the regrowth of perennial ryegrass sward

\begin{tabular}{|c|c|c|c|c|c|c|}
\hline \multirow{2}{*}{ Date } & \multirow{2}{*}{ Treatment } & \multirow{2}{*}{ Herbage } & \multicolumn{3}{|c|}{ Soil } & \multirow{2}{*}{$\mathrm{N}$ loss } \\
\hline & & & Total N & $\left(\mathrm{NH}_{4}^{+}-\mathrm{N}\right)$ & $\left(\mathrm{NO}_{3}^{-}-\mathrm{N}\right)$ & \\
\hline \multirow[t]{3}{*}{ Day 7} & Control & $4.0 \pm 0.1^{a}$ & $64.6 \pm 2.2^{\mathrm{a}}$ & $\left(27.4 \pm 0.8^{a}\right)$ & $\left(4.4 \pm 0.3^{\mathrm{a}}\right)$ & $31.4 \pm 2.1^{\mathrm{a}}$ \\
\hline & DCD & $3.9 \pm 0.2^{a}$ & $66.4 \pm 1.8^{\mathrm{a}}$ & $\left(28.1 \pm 0.9^{a}\right)$ & $\left(3.1 \pm 0.2^{b}\right)$ & $29.7 \pm 1.8^{a}$ \\
\hline & $\mathrm{HQ}+\mathrm{DCD}$ & $3.8 \pm 0.3^{a}$ & $70.4 \pm 1.2^{\mathrm{a}}$ & $\left(18.6 \pm 0.5^{b}\right)$ & $\left(2.4 \pm 0.1^{c}\right)$ & $25.8 \pm 1.3^{\mathrm{a}}$ \\
\hline \multirow[t]{2}{*}{ Day 14} & Control & $7.1 \pm 1.0^{\mathrm{a}}$ & $57.6 \pm 2.2^{c}$ & $\left(13.2 \pm 0.5^{a}\right)$ & $\left(12.5 \pm 1.5^{a}\right)$ & $35.3 \pm 1.3^{\mathrm{a}}$ \\
\hline & $\mathrm{HQ}+\mathrm{DCD}$ & $6.1 \pm 0.2^{a}$ & $67.4 \pm 2.3^{\mathrm{a}}$ & $\left(7.2 \pm 0.4^{c}\right)$ & $\left(9.3 \pm 0.7^{b c}\right)$ & $26.5 \pm 2.1^{b}$ \\
\hline \multirow[t]{4}{*}{ Day 56} & Control & $21.2 \pm 0.7^{b}$ & $40.8 \pm 2.0^{c}$ & $\left(0.9 \pm 0.1^{d}\right)$ & $\left(21.5 \pm 1.4^{d}\right)$ & $38.0 \pm 1.9^{a}$ \\
\hline & $\mathrm{HQ}$ & $28.2 \pm 1.7^{\mathrm{a}}$ & $44.9 \pm 1.0^{\mathrm{ab}}$ & $\left(1.5 \pm 0.1^{c}\right)$ & $\left(32.1 \pm 1.6^{b}\right)$ & $27.0 \pm 2.2^{b c}$ \\
\hline & $\mathrm{DCD}$ & $26.4 \pm 1.5^{\mathrm{a}}$ & $45.2 \pm 1.8^{\mathrm{ab}}$ & $\left(2.1 \pm 0.1^{b}\right)$ & $\left(29.4 \pm 1.5^{\mathrm{bc}}\right)$ & $28.4 \pm 1.4^{b}$ \\
\hline & $\mathrm{HQ}+\mathrm{DCD}$ & $30.2 \pm 0.9^{a}$ & $48.3 \pm 2.1^{\mathrm{a}}$ & $\left(2.4 \pm 0.1^{a}\right)$ & $\left(36.2 \pm 1.7^{\mathrm{a}}\right)$ & $21.6 \pm 2.2^{c}$ \\
\hline
\end{tabular}

Percentage of pig slurry-urea ${ }^{15} \mathrm{~N}$ in the soil inorganic $\mathrm{N}\left(\mathrm{NH}_{4}{ }^{+}-\mathrm{N}\right.$ or $\left.\mathrm{NO}_{3}-\mathrm{N}\right)$ pool.

The values are means \pm standard error of four replicates.

$H Q$, hydroquinone; DCD, dicyandiamide.

a-d Different letters in vertical column indicate significant differences at $p<0.05$ according to the Duncan's multiple range test.

of application of pig slurry. Cumulative $\mathrm{N}_{2} \mathrm{O}$ emission throughout the experimental period decreased by $40.7 \%, 59.8 \%$, and $50.0 \%$ in the HQ, DCD, and DCD+HQ plots compared with the control plot (Figure 5B). The weekly cumulative $\mathrm{NO}_{3}^{-}$ leaching was lower in the plots applied with the inhibitors, especially prior to $21 \mathrm{~d}$ after pig slurry application. Overall DCD application (e.g., DCD and HQ+DCD treatment) was more effective in reducing $\mathrm{NO}_{3}^{-}$leaching (Figure $4 \mathrm{C}$ ). $\mathrm{Cu}-$ mulative $\mathrm{NO}_{3}{ }^{-}$leaching for the whole experimental period declined by $7.0 \%, 12.9 \%$, and $11.8 \%$ in the HQ, DCD, and DCD+HQ plots, respectively, compared with the control plots (Figure 5C).

\section{DISCUSSION}

Regrowth and pig slurry-urea ${ }^{15} \mathrm{~N}$ recovery in herbage The efficacy of different types of urease inhibitors [HQ, phenyl phosphorodiamidate (PPDA), and N-(n-butyl) thiophosphoric triamide (NBPT)] and nitrification inhibitors (DCD, 3, 4-dimethylpyrazole phosphate [DMPP], Nitrapyrin, and thiosulphate) have been tested to improve $\mathrm{N}$ use efficiency while minimizing $\mathrm{N}$ losses to the environment. For instance, a meta-analysis of 113 field experiments showed that the effectiveness of various urease and nitrification inhibitors was relatively consistent across land use types in both chemical and organic $\mathrm{N}$ fertilizers [19]. In this context, we focused on urease inhibitor HQ and nitrification inhibitor DCD because HQ is lower cost [20], DCD is less volatile, and easily blended with fertilizers [5]. In the present study, single or combined HQ and DCD treatments did not influence the amount of NdfSU in herbage during the first $14 \mathrm{~d}$ of regrowth, whereas at the final regrowth $(56 \mathrm{~d})$ positive effects of HQ and/or DCD were observed, at which NdfSU was enhanced by $33.2 \%$ (on average 3 inhibitor treatments) compared with the control (Figure 1C). Consistent with NdfSU, the final herbage DM at $56 \mathrm{~d}$ significantly increased in the HQ and/or DCD applied plots (Figure 1A). This indicated that inorganic $\mathrm{N}$ might be more available during the later period of regrowth due to delayed hydrolysis of urea in pig slurry by $\mathrm{HQ}$, and reduced oxidation of $\mathrm{NH}_{4}{ }^{+}$to $\mathrm{NO}_{3}{ }^{-}$by DCD. In addition, these results indicated that early regrowth might be less dependent on exogenous $\mathrm{N}$ uptake by plants [21]. At final regrowth (56 d), the recovery of pig slurry-urea ${ }^{15} \mathrm{~N}$ varied within the range of $26.4 \%$ to $30.2 \%$ in the HQ and/or DCD applied plots, which was higher than that of the control (21.2\%) (Table 2). By using ${ }^{15} \mathrm{~N}$ tracing, Choi et al [22] revealed that $\mathrm{N}$ is produced from organic amendments and $\mathrm{N}$ uptake was more pronounced during the later growth period of Chinese cabbage.

\section{Soil mineralization and pig slurry-urea ${ }^{15} \mathrm{~N}$ recovery}

Plant uptake of $\mathrm{N}$ released from animal manure gradually increases with progressing regrowth of perennial grasses $[3,18,23]$. In the present study, at the final regrowth (56 d), we found a significant increase in herbage $\mathrm{N}$ content in the HQ+DCD plot, and NdfSU in herbage of all plots applied with the inhibitors (Figure 1B). However, the soil total $\mathrm{N}$ content was not affected by the inhibitors throughout the experimental period (Figure 2A). This indicates that enhanced $\mathrm{N}$ uptake and herbage growth in the HQ and/or DCD applied plots are due to inorganic $\mathrm{N}$ released from organic $\mathrm{N}$ rather than the $\mathrm{N}$ pool size in soil $[3,23]$. The NdfSU in the soil total $\mathrm{N}$ gradually decreased from 134.6 (at $7 \mathrm{~d}$ ) to 89.2 $\mathrm{kg} \mathrm{N} / \mathrm{ha}$ (at $56 \mathrm{~d}$ ) (based on average values of 4 treatments), 

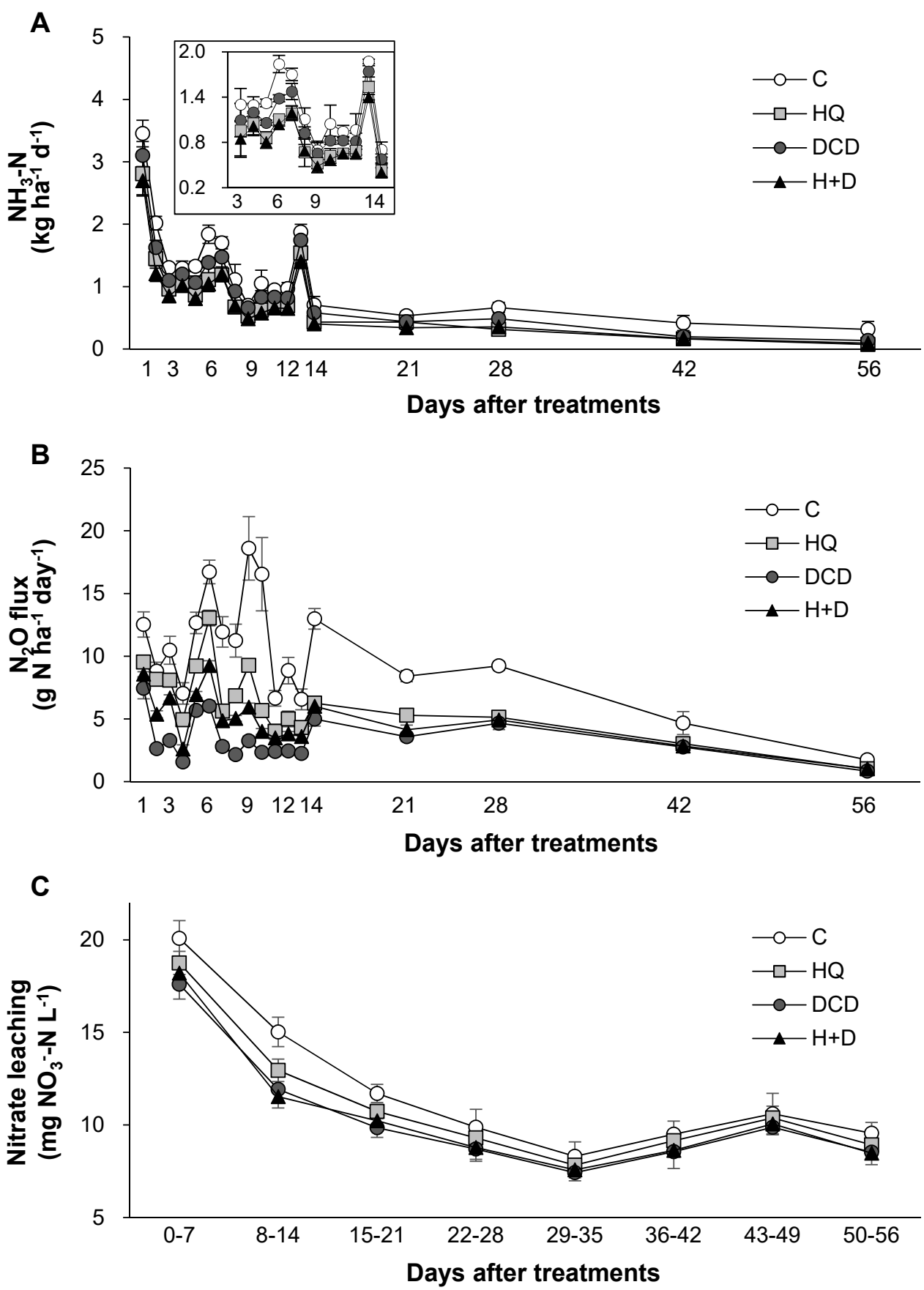

Figure 4. Daily emissions of ammonia (A) and nitrous oxide (B) and weekly accumulative nitrate concentration in leachate (C) from the control (O), urease inhibitor $(H Q,-)$, nitrification inhibitor $(D C D, \bullet)$ and the combination of $H Q$ and $D C D(H+D, \boldsymbol{\Delta})$ during regrowth of perennial ryegrass sward. $H Q$, hydroquinone; DCD, dicyandiamide.

corresponding to a decrease of ${ }^{15} \mathrm{~N}$ recovery in soil from $67.0 \%$ to $44.8 \%$ (Figure 2). This implies that $\mathrm{N}$ released from the applied urea in pig slurry dilutes the soil inorganic $\mathrm{N}$ pool, which is available for herbage regrowth. However, the NdfSU in herbage was not significantly affected by HQ and/or DCD application during the first $14 \mathrm{~d}$ of regrowth, although the amount of $\mathrm{N}$ derived from the pig slurry-urea in the soil $\mathrm{NH}_{4}^{+}\left(\mathrm{NdfSU}-\mathrm{NH}_{4}^{+}\right.$) or $\mathrm{NO}_{3}^{-}$fractions (NdfSU-NO ${ }_{3}^{-}$) de- creased in the HQ and/or DCD treatments from $7 \mathrm{~d}$ (Figure 3). This may reflect a common $\mathrm{N}$ utilization pattern during the early regrowth characterized by low exogenous $\mathrm{N}$ uptake because shoot regrowth during this period depends on a large portion of endogenous $\mathrm{N}$ rather than exogenous $\mathrm{N}$ uptake [21]. In addition, during the first $7 \mathrm{~d}$ of regrowth, urea ${ }^{15} \mathrm{~N}$ in pig slurry was mineralized mainly to $\mathrm{NH}_{4}{ }^{+} \mathrm{N}$, which accounted for $63.6 \%$ to $88.6 \%$ of total NdfSU in the soil min- 

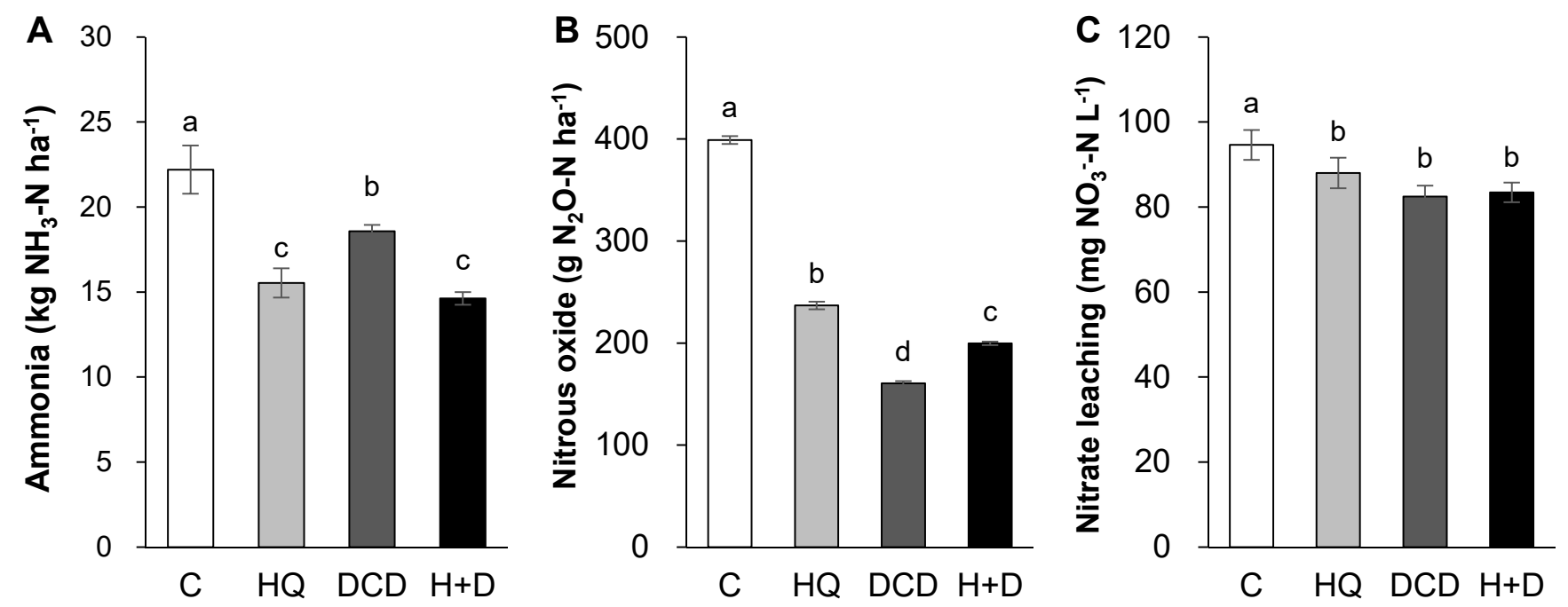

Figure 5. Total emission of ammonia (A) and nitrous oxide (B) and nitrate leaching (C) as estimated by cumulative amount for 56 days of regrowth a-d Different letters indicate significant differences at $p<0.05$ according to the Duncan's multiple range test.

eral N (sum of NdfSU-NH ${ }_{4}^{+}$and NdfSU-NO ${ }_{3}^{-}$) (Figure 3). The NdfSU- $\mathrm{NH}_{4}^{+}$was lower in the plots applied with the inhibitors, especially in the presence of HQ (e.g., HQ and HQ+ DCD treatments) during the first $14 \mathrm{~d}$, suggesting that HQ delayed the hydrolysis of urea in pig slurry [7]. The NdfSU$\mathrm{NH}_{4}{ }^{+}$in soil slowed down with progressing regrowth with an opposite increase in the NdfSU- $\mathrm{NO}_{3}^{-}$(Figure 3B, D), reflecting nitrification of the $\mathrm{NH}_{4}{ }^{+}$released from pig slurryurea. The NdfSU- $\mathrm{NO}_{3}{ }^{-}$in the soil at $56 \mathrm{~d}$ of regrowth was significantly higher in the presence of the inhibitors, especially in the presence of DCD (e.g., DCD and HQ+DCD treatments), compared with the control (Figure 3). At the final regrowth (56 d), the $\mathrm{N}$ content converted to soil inorganic $\mathrm{N}$ from pig slurry-urea (NdfSU- $\mathrm{NH}_{4}{ }^{+}+\mathrm{NdfSU}-\mathrm{NO}_{3}^{-}$) was higher in the presence of DCD (70.4 to $77.3 \mathrm{~kg} \mathrm{~N} / \mathrm{ha}$ ) compared to that of control ( $60.0 \mathrm{~kg} \mathrm{~N} / \mathrm{ha}$ ) (Figure 3). Retention of higher NdfSU-NH${ }_{4}^{+}$and NdfSU-NO ${ }_{3}^{-}$in the soils amended the inhibitors may reflect the active onset of hydrolysis of urea and subsequent nitrification during the latter regrowth period when the uptake of exogenous $\mathrm{N}$ strongly occurs as a primary $\mathrm{N}$ source for the herbage regrowth [21]. Thus, enhanced final regrowth yield (Figure 1A) and higher NdfSU in herbage at $56 \mathrm{~d}$ (Figure 1C) in the HQ and/or DCD plots are certainly attributed to the higher availability of $\mathrm{N}$ released from pig slurry, as evidenced by higher percentages of urea ${ }^{15} \mathrm{~N}$ recovered in the soil inorganic N, i.e., $38.6 \%, 33.6 \%$, and $31.5 \%$ of the ${ }^{15} \mathrm{~N}$ applied in the DCD, HQ, and HQ+DCD plots, respectively, compared with the control (22.4\%). Many studies have shown positive effects of urease and/or nitrification inhibitors on plant nutrient availability in soil, enhancing yields of annual crops $[24,25]$ and herbage in perennial grasslands [26].
$\mathrm{N}$ losses via $\mathrm{NH}_{3}, \mathrm{~N}_{2} \mathrm{O}$ emissions, and $\mathrm{NO}_{3}{ }^{-}$leaching Although the $\mathrm{N}$ in animal manure, especially for urine where urea makes up $65 \%$ to $90 \%$ of $\mathrm{N}$, is economically attractive, it may also result in environmental pollution via $\mathrm{N}$ losses as odorous gases (e.g., $\mathrm{NH}_{3}$ and $\mathrm{H}_{2} \mathrm{~S}$ ), greenhouse gases (e.g., $\mathrm{N}_{2} \mathrm{O}$ and $\mathrm{CH}_{4}$ ) and $\mathrm{NO}_{3}^{-}-\mathrm{N}$ leaching when inefficiently used by plants. The options using inhibitors of the $\mathrm{N}$ cycle, such as urease and nitrification inhibitors, have been evaluated to mitigate $\mathrm{N}$ losses from chemical $\mathrm{N}$ fertilizers, mainly urea $[25,27]$ and from animal manure [28]. The present ${ }^{15} \mathrm{~N}$ recovery data has shown that $38.0 \%, 27.0 \%, 28.4 \%$, and $21.6 \%$ of applied $\mathrm{N}$ were unaccounted in the control, HQ, DCD, and HQ+DCD plots, respectively (Table 2). In this study, these percentages were designated as the estimated $\mathrm{N}$ loss and the noxious $\mathrm{N}$ losses to $\mathrm{NH}_{3}, \mathrm{~N}_{2} \mathrm{O}$ emission, and $\mathrm{NO}_{3}{ }^{-}$ leaching.

The application of animal manure causes $\mathrm{NH}_{3}$ volatilization via the $\mathrm{N}$ decomposition present in the feces and urea hydrolysis. Urea is hydrolyzed by urease and produces $\mathrm{NH}_{3}$ and carbonic acid. Thus, significant enhancement of daily $\mathrm{NH}_{3}$ emission after animal manure application has been observed in various cropping systems [23,29]. In the present study, daily $\mathrm{NH}_{3}$ emission significantly reduced in the presence of HQ (e.g., HQ and HQ+DCD plots) during the first $14 \mathrm{~d}$ (Figure $4 \mathrm{~A}$ ), when a large portion of $\mathrm{NH}_{3}$ emission (58.8\%, averaged over 4 treatments, of total $\mathrm{NH}_{3}$ emission) occurred (Figure 5A). This result indicates that the urease inhibitor $\mathrm{HQ}$ efficiently abates the pool of $\mathrm{NH}_{4}^{+}$(Figure 3A) by slowing the hydrolysis of urea, which alleviates the subsequent $\mathrm{NH}_{3}$ emission, especially during the early period. Zhengping et al [20] estimated in the laboratory incubation that a urease inhibitor NBPT decreased $\mathrm{NH}_{3}$ volatilization 
by $18 \%$ after $14 \mathrm{~d}$ of incubation, while PPDA decreased $\mathrm{NH}_{3}$ volatilization by $9 \%$ after $10 \mathrm{~d}$.

$\mathrm{N}_{2} \mathrm{O}$ emission from animal manure is associated with soil mineralization processes because $\mathrm{N}_{2} \mathrm{O}$ is generated primarily through microbial nitrification of $\mathrm{NH}_{4}^{+}$to $\mathrm{NO}_{2}^{-}$and then $\mathrm{NO}_{3}^{-}$; and denitrification of $\mathrm{NO}_{3}^{-}$to $\mathrm{N}_{2} \mathrm{O}$ [28]. In the present study, daily $\mathrm{N}_{2} \mathrm{O}$ emissions ranged from 0.84 to $18.60 \mathrm{~g}$ $\mathrm{N}_{2} \mathrm{O}-\mathrm{N} / \mathrm{ha} / \mathrm{d}$. The significant reduction of $\mathrm{N}_{2} \mathrm{O}$ emission by DCD treatments, as estimated by $59.8 \%$ of reduction by DCD alone and $50.0 \%$ by HQ+DCD compared with the control (Figure 6B), suggested that the nitrification inhibitor DCD deactivates the enzymes responsible for the oxidation of $\mathrm{NH}_{4}{ }_{4}$, reducing its conversion to $\mathrm{NO}_{3}{ }^{-}$, which limits the pool of denitrification for $\mathrm{N}_{2} \mathrm{O}$ emission [5] as well as susceptible leaching [6]. The present data showed that the urease inhibitor HQ also significantly reduced $\mathrm{N}_{2} \mathrm{O}$ emission by $40.7 \%$ compared to the control, confirming that HQ plays an important role in reducing $\mathrm{N}_{2} \mathrm{O}$ emission by reducing the pool of $\mathrm{NH}_{4}{ }^{+}$released from urea hydrolysis (Figure 3A), which is a primary source of nitrification and of following denitrification $[5,9]$. The stronger effect of nitrification inhibitors, compared with that of the urease inhibitor, on reducing $\mathrm{N}_{2} \mathrm{O}$ emission has also been shown in several crop fields applied with urea [9]. Nitrification inhibitors have been shown to successfully reduce $\mathrm{N}_{2} \mathrm{O}$ emission from various cropping systems [24,27] and pastures [26].

In this study, positive effects of HQ and/or DCD in reducing $\mathrm{NO}_{3}^{-}$leaching from the soil were observed, as demonstrated by $7.0 \%, 12.9 \%$, and $11.8 \%$ reductions in $\mathrm{NO}_{3}^{-}$leaching in the soil in the HQ, DCD, and HQ+DCD plots, respectively. This result may reflect the priming effect of the inhibitors on delaying nitrification, as shown by the lower level of soil $\mathrm{NO}_{3}^{-}$(Figure $3 \mathrm{C}$ ) and slightly higher $\mathrm{NH}_{4}{ }^{+}$ (Figure 3A). Other studies have shown that nitrification inhibitors efficiently reduced $\mathrm{NO}_{3}^{-}$leaching from the soil amended with $\mathrm{NH}_{4}^{+}$-based $\mathrm{N}$ fertilizer (including ureabased or other organic amendments, which subsequently convert to $\mathrm{NH}_{4}^{+}$) by retaining $\mathrm{N}$ in the soil $\mathrm{NH}_{4}{ }^{+}$form over a longer period, reducing the peak concentration of soil $\mathrm{NO}_{3}^{-}$and the potential for $\mathrm{N}$ losses through denitrification or $\mathrm{NO}_{3}^{-}$leaching from the soil [30]. In addition, Zaman and Blennerhassett [14] revealed that the addition of urease inhibitor NBPT reduces $\mathrm{NO}_{3}{ }^{-}$leaching to a greater extent for synthetic fertilizer and animal excreta.

In conclusion, with progressing regrowth of perennial ryegrass pasture, the uptake of applied pig slurry-urea ${ }^{15} \mathrm{~N}$ by herbage gradually increases, whereas soil urea ${ }^{15} \mathrm{~N}$ recovery decreased. The herbage urea ${ }^{15} \mathrm{~N}$ recovery was not affected by the application of HQ and/or DCD during the first $14 \mathrm{~d}$ of regrowth. However, at the final regrowth (56 d), application of HQ and/or DCD resulted in an increase in urea ${ }^{15} \mathrm{~N}$ recovery in both the herbage and soil, with the strongest effect observed for HQ+DCD. The conversion of pig slurry ureaderived $\mathrm{N}$ into soil $\mathrm{NH}_{4}^{+}$and $\mathrm{NO}_{3}^{-}$fractions were reduced by the inhibitors, with a higher effect observed for HQ during the first $14 \mathrm{~d}$. The conversion of pig slurry-urea $\mathrm{N}$ into soil $\mathrm{NH}_{4}{ }^{+}$and $\mathrm{NO}_{3}{ }^{-}$fractions was enhanced especially in the presence of DCD during the latter regrowth period. Higher retention of soil inorganic $\mathrm{N}$ derived from pig slurry-urea at the final regrowth (56 d) in the HQ and/or DCD plots was in line with the enhanced herbage $\mathrm{N}$ recovery as well as the reduced $\mathrm{N}$ losses. The application of $\mathrm{HQ}$ and/or DCD resulted in the efficient reduction of $\mathrm{NH}_{3}, \mathrm{~N}_{2} \mathrm{O}$ emission, and $\mathrm{NO}_{3}^{-}$leaching. Application of HQ or DCD alone also significantly reduced $\mathrm{N}$ losses. Therefore, it can be concluded that HQ and DCD efficiently improve the N use efficiency of pig slurry-urea, contributing a positive role in reducing $\mathrm{N}$ losses to the environment.

\section{IMPLICATIONS}

Management strategies of animal manure are necessary to improve nitrogen use efficiency while minimizing $\mathrm{N}$ losses to environmental pollution. The application of urease inhibitor (hydroquinone) and/or nitrification inhibitor (dicyandiamide) may enhance the nitrogen use efficiency of pig slurry by delaying the hydrolysis of urea and nitrification, thereby alleviating the nitrogen losses to nitrate leaching, ammonia, and nitrous oxide emission. Appropriate utilization of urease and nitrification inhibitors for pig slurry application to the grassland would be an efficient way to improve the nitrogen use efficiency, leading to a significant reduction of nitrate leaching and hazardous gases emission to the atmosphere.

\section{CONFLICT OF INTEREST}

We certify that there is no conflict of interest with any financial organization regarding the material discussed in the manuscript.

\section{ACKNOWLEDGMENTS}

This research is supported by the National Research Foundation of South Korea (NRF-2019R1A6A3A01092319).

\section{REFERENCES}

1. Spiertz JHJ. Nitrogen, sustainable agriculture and food security. A review. Agron Sustain Dev 2010;30:43-55. https://doi.org/ 10.1051/agro:2008064

2. Bristow AW, Whitehead DC, Cockburn JE. Nitrogenous constituents in the urine of cattle, sheep and goats. J Sci Food Agric 1992;59:387-94. https://doi.org/10.1002/jsfa.274059 0316 
3. Park SH, Lee BR, Cho WM, Kim TH. Comparative nitrogen use efficiency of urea and pig slurry for regrowth yield and nutritive value in perennial ryegrass sward. Asian-Australas J Anim Sci 2017;30:514-22. https://doi.org/10.5713/ajas.16. 0520

4. Ju XT, Xing GX, Chen XP, et al. Reducing environmental risk by improving $\mathrm{N}$ management in intensive Chinese agricultural systems. Proc Natl Acad Sci USA 2009;106:3041-6. https://doi.org/10.1073/pnas.0813417106

5. Gilsanz C, Báez D, Misselbrook TH, Dhanoa MS, Cárdenas LM. Development of emission factors and efficiency of two nitrification inhibitors, DCD and DMPP. Agric Ecosyst Environ 2016:216:1-8. https://doi.org/10.1016/j.agee.2015. 09.030

6. Guo Y, Li B, Di H, Zhang L, Gao Z. Effects of dicyandiamide (DCD) on nitrate leaching, gaseous emissions of ammonia and nitrous oxide in a greenhouse vegetable production system in northern China. Soil Sci Plant Nutr 2012;58:64758. https://doi.org/10.1080/00380768.2012.726921

7. Martins MR, Sant'Anna SAC, Zaman M, et al. Strategies for the use of urease and nitrification inhibitors with urea: Impact on $\mathrm{N}_{2} \mathrm{O}$ and $\mathrm{NH}_{3}$ emissions, fertilizer- ${ }^{15} \mathrm{~N}$ recovery and maize yield in a tropical soil. Agric Ecosyst Envion 2017;247: 54-62. https://doi.org/10.1016/j.agee.2017.06.021

8. Xi R, Long XE, Huang S, Yao H. pH rather than nitrification and urease inhibitors determines the community of ammonia oxidizers in a vegetable soil. AMB Express 2017;7:129. https:// doi.org/10.1186/s13568-017-0426-x

9. Hube S, Alfaro MA, Scheer C, et al. Effect of nitrification and urease inhibitors on nitrous oxide and methane emissions from an oat crop in a volcanic ash soil. Agric Ecosyst Envrion 2017;238:46-54. https://doi.org/10.1016/j.agee.2016.06.040

10. Mira AB, Cantarella H, Souza-Netto GJM, Moreira LA, Kamogawa MY, Otto R. Optimizing urease inhibitor usage to reduce ammonia emission following urea application over crop residues. Agric Ecosyst Environ 2017;248:105-12. https:// doi.org/10.1016/j.agee.2017.07.032

11.Barth G, von Tucher S, Schmidhalter U. Influence of soil parameters on the effect of 3,4-dimethylpyrazole-phosphate as a nitrification inhibitor. Biol Fertil Soils 2001;34:98-102. https://doi.org/10.1007/s003740100382

12. Abalos D, Sanz-Cobena A, Andreu G, Vallejo A. Rainfall amount and distribution regulate DMPP effects on nitrous oxide emissions under semiarid Mediterranean conditions. Agric Ecosyst Environ 2017;238:36-45. https://doi.org/10. 1016/j.agee.2016.02.003

13.Li X, Zhang G, Xu H, Cai Z, Yagi K. Effect of timing of joint application of hydroquinone and dicyandiamide on nitrous oxide emission from irrigated lowland rice paddy field. Chemosphere 2009;75:1417-22. https://doi.org/10.1016/j. chemosphere.2009.02.006

14.Zaman M, Blennerhassett JD. Effects of the different rates of urease and nitrification inhibitors on gaseous emissions of ammonia and nitrous oxide, nitrate leaching and pasture production from urine patches in an intensive grazed pasture system. Agric Ecosyst Environ 2010;136:236-46. https://doi. org/10.1016/j.agee.2009.07.010

15. Ndegwa PM, Vaddella VK, Hristov AN, Joo HS. Measuring concentrations of ammonia in ambient air or exhaust air stream using acid traps. J Environ Qual 2009;38:647-653. https://doi.org/10.2134/jeq2008.0211

16. Kim TH, Kim BH. Ammonia microdiffusion and colorimetic method for determining nitrogen in plant tissues. J Kor Soc Grassl Sci 1996;16:253-9.

17. Hamonts K, Ryngaert A, Smidt H, Springael D, Dejonghe W. Determinants of the microbial community structure of eutrophic, hyporheic river sediments polluted with chlorinated aliphatic hydrocarbons. FEMS Microbiol Ecol 2014;87:715732. https://doi.org/10.1111/1574-6941. 12260

18. Park SH, Lee BR, Jung KH, Kim TH. Acidification of pig slurry effects on ammonia and nitrous oxide emissions, nitrate leaching, and perennial ryegrass regrowth as estimated by ${ }^{15} \mathrm{~N}$-urea flux. Asian-Australas J Anim Sci 2018;31:45766. https://doi.org/10.5713/ajas.17.0556

19. Akiyama H, Yan X, Yagi K. Evaluation of effectiveness of enhanced-efficiency fertilizers as mitigation options for $\mathrm{N}_{2} \mathrm{O}$ and $\mathrm{NO}$ emissions from agricultural soils: meta-analysis. Glob Change Biol 2010;16:1837-46. https://doi.org/10.1111/j.13652486.2009.02031.x

20.Zhengping W, Van Cleemput O, Demeyer P, Baert L. Effect of urease inhibitors on urea hydrolysis and ammonia volatilization. Biol Fertil Soils 1991;11:43-7. https://doi.org/10.1007/ BF00335833

21. Ourry A, Bourcaud J, Salette J. Partitioning and remobilization of nitrogen during regrowth in nitrogen-deficient ryegrass. Crop Sci 1990;30:1251-4. https://doi.org/10.2135/ cropsci1990.0011183X003000060019x

22. Choi WJ, Ro HM, Chang SX. Recovery of fertilizer-derived inorganic ${ }^{15} \mathrm{~N}$ in a vegetable field soil as affected by application of an organic amendment. Plant Soil 2004;263:191201. https://doi.org/10.1023/B:PLSO.0000047726.09394.d3

23. Hoekstra NJ, Lalor STJ, Richards KG, et al. Slurry ${ }^{15} \mathrm{NH}_{4}-\mathrm{N}$ recovery in herbage and soil: effects of application method and timing. Plant soil 2010;330:357-68. https://doi.org/10. 1007/s11104-009-0210-z

24. Banerjee B, Pathak H, Aggarwal P. Effects of dicyandiamide, farmyard manure and irrigation on crop yields and ammonia volatilization from an alluvial soil under a rice (Oryza sativa L.)-wheat (Triticum aestivum L.) cropping system. Biol Fertil Soils 2002;36:207-14. https://doi.org/10.1007/s00374-0020528-7

25.Zhang L, Wu Z, Jiang Y, et al. Fate of applied urea ${ }^{15} \mathrm{~N}$ in a soil-maize system as affected by urease inhibitor and nitrification inhibitor. Plant Soil Environ 2010;56:8-15. https://doi. 
org/10.17221/129/2009-PSE

26. Rowling DW, Scheer C, Liu S, Grace PR. Annual nitrogen dynamics and urea fertilizer recoveries from a dairy pasture using ${ }^{15} \mathrm{~N}$; effect of nitrification inhibitor DMPP and reduced application rates. Agric Ecosyst Environ 2016;216:216-25. https://doi.org/10.1016/j.agee.2015.09.025

27.Liu S, Wang JJ, Tian Z, Wang X, Harrison S. Ammonia and greenhouse gas emissions from a subtropical wheat field under different nitrogen fertilization strategies. J Environ Sci 2017;57:196-210. https://doi.org/10.1016/j.jes.2017.02. 014

28. Meijide A, Diez JA, Sanchez-Martin L, Lopez-Fernandez S, Vallejo A. Nitrogen oxide emissions from an irrigated maize crop amended with treated pig slurries and composts in a Mediterranean climate. Agric Ecosyst Environ 2007;121:38394. https://doi.org/10.1016/j.agee.2006.11.020

29. Fangueiro D, Surgy S, Coutinho J, Vasconcelos E. Impact of cattle slurry acidification on carbon and nitrogen dynamics during storage and after soil incorporation. J Plant Nutr Soil Sci 2013;176:540-50. https://doi.org/10.1002/jpln.201200117

30.Di HJ, Cameron KC. The use of a nitrification inhibitor, dicyandiamide (DCD), to decrease nitrate leaching and nitrous oxide emissions in a simulated grazed and irrigated grassland. Soil Use Manage 2002;18:395-403. https://doi.org/ 10.1111/j.1475-2743.2002.tb00258.x 